\title{
Islamic Rule and Iranian Women in the Films of Hatef Alimardani
}

\begin{abstract}
This article reconsiders some Western textual and visual (mis)representations of Muslim women as mentally imprisoned by Islamic rules and patriarchy through analyzing three prominent films by the Iranian screenwriter and director, Hatef Alimardani (b. 1976). It begins by a brief discussion of the portrayals of women in Islamic societies promulgated by Anglo-American media. Then, by examining For Pooneh's Sake (Beh Khāter-e Pooneh, 2013), The Nameless Alley (Kucheh-ye Binām, 2015), and $\bar{A} b \bar{a} J a ̄ n$ (2017), box-office hits offering sociocultural critiques through realistic cinematic depictions of contemporary Iranian society, it demonstrates how Alimardani's films dismantle stereotypical and essentialist portrayals of Muslim women by Western media and scholarly works, and thus, help us better understand the lived experience of women in Islamic countries.
\end{abstract}

Keywords: Veiling, Islamic Rules, Patriarchy, Muslim Women, Iranian Cinema, Iranian Women, Hatef Alimardani.

\section{Introduction}

The textual and visual representations we encounter daily through journals, books, movies, and other media constitute one of our main sources of information about foreign countries and their residents. In forming our perceptions of other places and peoples, as Nickianne Moody proposes, popular and mass media, such as the television and the cinema, are especially significant "sites of cultural practice" for they connect "popular culture directly to ways of thinking, feeling, and acting in the world" and thus function as "shared cultural reference points," reflecting the dominant "ideologies, 
discourses, and values" in a given society. ${ }^{1}$ Therefore, studying cinematic representations of a society, especially those produced by its own members "internally" and received popularly by its domestic audience, in contrast to those produced by outsiders and for an "external" or international viewership, offers us credible and unique insights into the lived experiences, values, and ideologies of its people. These internally produced and consumed works are particularly important as their production and consumption indicate the extent to which the members of the society in and for which the work was produced identify with and accept their world represented and portrayed in it. And studying these internally made cultural products enables us a more direct and immediate understanding of the society for and in which they were made, and thus liberate us from reliance on (mis)understandings generated by external observers and commentators, whose views shall always be examined closely and critically.

When it comes to representations of Muslim societies, cultural reference points, such as the cinema, are noteworthy for the medium of cinema is one of the most popular media of representation in our contemporary world. However, we should be cognizant that all representations of Muslim countries, cinematic or otherwise, especially those produced externally by members of outside societies and for an outside and often international audience, are not completely unbiased and credible; therefore, to better understand these countries and their people, we should critically examine the textual and visual portrayals to which we are exposed.

A spate of Western books, television shows, and movies portray Muslim women as victims of their patriarchal society, living a life of immobility, enslavement, and voicelessness. Western commentators usually present the Islamically-mandated veil, enforced in countries, such as Iran, Afghanistan, and Saudi Arabia, as the ultimate sign and symbol of women's subjugation. For them, the veil is the indisputable "marker of gender equality," thus, the veiled Muslim women are routinely portrayed and perceived as oppressed and subjugated, while Islam is understood as a misogynist and irredeemably patriarchal religion. ${ }^{2}$ Among the most notable recent books, promoting this mode of reasoning, one could mention The Caged Virgin: A Muslim Woman's Cry for Reason (2004) and Infidel: My Life (2007) by Ayaan Hirsi Ali (b. 1969), the DutchAmerican activist, whom the Time magazine named one of the one hundred influential people of 2005 and the Foreign Policy journal ranked as one of the top-twenty international public intellectuals in 2008. In her books, Hirsi Ali portrays Muslim

\footnotetext{
${ }^{1}$ Moody, "Feminism and Popular Culture," 172.

${ }^{2}$ Irene Zempi and Neil and Neil Chakraborti, Islamophobia, Victimisation and the Veil, 2.
} 
women as caged and enslaved beings in mental bars forged and erected by Islam and Islamic patriarchy. ${ }^{3}$ Despite her fame in the Western world as a spokesperson for Muslim women, as observed by Hamid Dabashi, Hirsi Ali, an outsider writing externally about the reality of Muslim women's lives, is an "Islamophobe," ${ }^{4}$ promoting "virulent Islamophobia." 5

Among the most notable television shows and movies misrepresenting Muslim women, one could mention the American television series Homeland by the Showtime channel, and the film Circumstances (2011), produced by an American director in Lebanon. Homeland, which recounts the stories of various CIA missions in the Middle East, has been criticized for its stereotypical, bigoted, and racist portrayals of Muslim men and women. ${ }^{6}$ In addition, Circumstance, which purports to portray and critique the problems of homosexual women in contemporary Iran, a worthy subject of discussion and analysis in its own right, has deviated to stereotypical and voyeuristic representations of two Muslim girls in a Muslim society. In the view of the late Roger Ebert, the film suffers from "unlikely melodrama and distracting eroticism" as it has resorted to "cinematic voyeurism," representing its subject.

In addition to such popular textual and visual misrepresentations, some scholarly works also reproduce the stereotypical perceptions of veiled Muslim women as hopelessly oppressed and imprisoned. According to Nancy J. Hirschmann,

Western feminists as well as nonfeminists often consider veiling an inherently oppressive practice. Many analogize it to domestic violence: just as staying with an abuser seems beyond comprehension, so does "choosing" the veil. Women who claim to do so are seen as brainwashed or coerced, and the veil as a key emblem of their oppression. ${ }^{8}$

Some of the major problematic underlying assumptions of such views of the relationship between the veil and the Islamic patriarchy are that patriarchy, as an institution, ideology, and mode of thinking is uniform and homogenous, exerts its power over all the men and women in Muslim societies consistently, and all men and women are forced to unquestionably follow its mandates.

\footnotetext{
3 Milani, Words not Swords, 209.

4 Dabashi, Being a Muslim, 11.

5 Ibid., 10.

${ }^{6}$ Al-Arian, “TV's Most Islamophobic Show”; Durkay, “'Homeland' is the Most Bigoted Show on

Television."

7 Ebert, "Sex and the Islamic City."

${ }^{8}$ Hirschmann, The Subject of Liberty, 176.
} 
It is worth noting that the Western feminists espousing such views do not make such assumptions merely about women in Muslim societies but also about women in Western societies. In the view of some Anglo-American feminists the patriarchy is forcefully regulating women's fates and oppressing their agency. Two of the main assumptions of these feminisms are that "women are oppressed by patriarchy economically, politically, socially, and psychologically" and "in every domain where patriarchy reigns, woman is other: she is objectified and marginalized, defined only by her difference from male norms and values, defined by what she (allegedly) lacks and that men (allegedly) have." ${ }^{9}$ Nevertheless, some recent scholarship has challenged such essentialist readings of the power of patriarchy and the powerlessness of women and men living under its control, and has proposed instead that we should problematize the preoccupation with "patriarchal programming" and take into account that "no ideology succeeds in fully programming all of the people all of the time."10 Consequently, in any study of women's sociocultural condition in a given society we should consider the myriad ways through which women resist, challenge, or transcend patriarchal limitations. Moreover, we should dismantle the notion that men are or consider themselves to be somewhat superior to women as it is a construct of the patriarchal worldview, and, as such, it does not universally apply to the conditions and real-life experiences of men and women everywhere.

Challenging stereotypical perceptions and representations of veiled Muslim women, Lila Abu-Lughod proposes that "we need to work against the reductive interpretation of veiling as the quintessential sign of women's unfreedom, even if we object to state imposition of this form, as in Iran or with the Taliban." ${ }^{11}$ In her opinion, because "humans are social beings, raised in certain social and historical contexts and belonging to particular communities that shape their desires and understandings of the world," ${ }^{12}$ their identities and agencies cannot be reduced to an item of clothing. In the same regard, Leila Ahmed contends that veiling is not merely a restrictive measure on women but also can have several "decidedly practical advantages." Wearing the veil "signals the wearer's adherence to an Islamic moral and sexual code," thus enables her to socialize with men and be seen in public without the fear of being considered immoral. ${ }^{13}$ In other words, by observing the veiling code, Muslim women establish their religiosity and create a sociocultural accepted sphere for themselves as the

\footnotetext{
9 Tyson, Critical Theory Today, 92.

${ }^{10}$ Ibid., 93.

${ }^{11}$ Abu-Lughod, Do Muslim Women Need Saving?, 40.

${ }^{12}$ Ibid.

${ }^{13}$ Ahmed, Women and Gender in Islam, 224.
} 
adoption of the Islamically-mandated "dress does not declare women's place to be in the home but, on the contrary, legitimizes their presence outside it."14

A similar argument has been made against essentialist and stereotypical representations of Iranian women living in the Islamic Republic of Iran, where veiling is compulsory in all public spaces. Although the Islamic Republic has imposed and enforced the hijab as an essential component of its state ideology as well as gender politics, ${ }^{15}$ and as a "symbol of reasserting Islamic identity and purification of society from Western culture," which it regards unacceptable and damaging to its interpretation of Islamic values, ${ }^{16}$ as Ziba Mir-Hosseini contends, the imposition of hijab by the Islamic state has not been a completely restrictive action since "by making public space morally correct in the eyes of the traditional families, it has legitimized women's public presence." ${ }^{17}$ Thus, it has created a public space for women and has facilitated their sharing this space with the male members of society. Furthermore, the patriarchal view inherent in the state ideology of the Islamic Republic of Iran does not control and limit all domains of women's lives in Iran and women are not, as some Western commentators and academics propose, mentally imprisoned by the compulsory veiling. Criticizing unrealistic textual and visual representations of women in Iran, Farzaneh Milani warns against taking for granted the trope of the captive Muslim women, which has become "an essential part of the dominant discourse on Islam," especially in the United States. ${ }^{18}$ As observed by Juliane Hammer, such misconceptions of Muslim women have become prevalent in the American society, where, "As objects of anti-Islamic discourse, Muslim women are represented as victims of their religion, culture, and Muslim men, and thus in need of saving, liberation, and intervention." 19 Against such bleak portrayals of Muslim women, especially in Iran, Milani's maintains,

Never before in the written history of Iran have women moved so far outside the framework preordained by their culture, reaching beyond the traditional fields in action

\footnotetext{
${ }^{14}$ Ibid.

${ }^{15}$ According to Haleh Afshar under the Islamic Republic, Iranian women must negotiate with "both a constitutional demand that women should be situated within the household and a Quranic dictum that men are the providers for women and therefore in charge." Thus, they need to come to terms with "the reality that even violence within the confines of the home" is considered permissible according to the Quran. Afshar, Islam and Feminisms, 150.

${ }^{16}$ Moghissi, Populism and Feminism in Iran, 184.

${ }^{17}$ Mir-Hosseini, Islam and Gender: The Religious Debate in Contemporary Iran, 7.

${ }^{18}$ Milani, Words not Swords, 211.

${ }^{19}$ Hammer, "Center Stage," 110.
} 
and imagination. Never before have they been as present in the public square and the public discourse as they are today. ${ }^{20}$

In this light, although the problematic compulsory hijab functions as a limiting sociopolitical mechanism imposed by the religious establishment on Iranian women, it nonetheless does not prevent women from performing various social roles and forming and performing their own cultural agency and identity, and moreover it does not enable all men to conform to and take advantage of an absolute form of patriarchal authority.

To challenge Western misrepresentations of Muslim women living in Islamic societies and gain a better understanding of the lived experiences of Muslim women, we examine the influence of the compulsory hijab and the patriarchy in the lives of the traditional-conservative and modern-liberal Iranian women by analyzing three prominent recent Iranian films by Hatef Alimardani. The popularity of these films among the Iranian viewers, as indicated by their tremendous success in the box-office, makes them particularly worthy of our analytical attention. Although, as pointed out by Nasrin Rahimieh, contemporary Iranian cinema cannot be facilely regarded as "simple representation of life" in Iran, certain Iranian films offer "collective and national self-examination" of Iranian society. ${ }^{21}$ Among contemporary Iranian films best representing this ethos are those of Hatef Alimardani, who deals with some of the central sociocultural challenges of Iranian women in his works. By focusing on films made by an eminent Iranian filmmaker whose films are produced for and welcomed by a large and variegated Iranian viewership, we will go beyond stereotypical portrayals of Muslim women and see how the compulsory hijab and the patriarchy do not unchallengedly define or delimit Iranian women.

Alimardani belongs to a group of young Iranian filmmakers, ${ }^{22}$ who, as Saeed Zeydabadi-Nejad maintains, explore, discuss, and critique social issues in their "social films" for an Iranian audience. ${ }^{23}$ As the screenwriter and director of For Pooneh's Sake (2013), The Nameless Alley (2015), and Ābā Jān (2017), Alimardani introduces his viewers to the complexities of contemporary Iranian society, and portrays conservative

\footnotetext{
${ }^{20}$ Ibid., 244.

${ }^{21}$ Rahimieh maintains that the Iranian society is experiencing "a collective soul searching” and "a process of transformation," which contemporary Iranian cinema has attempted to capture. Rahimieh, "Capturing Cultural Transformation," 195.

${ }^{22}$ For a critical and comprehensive overview of different trends and movements in Iranian cinema since its inception in the country during the early nineteenth century, see Naficy,

A Social History of Iranian Cinema, 4 vols.

${ }^{23}$ Zeydabadi-Nejad, The Politics of Iranian Cinema, 55
} 
and modern Iranian women, who do not allow the government-mandated hijab and their patriarchal society determine and define their identity and agency. In his works, he represents Iranian women as strong and intelligent individuals who know how to forge ahead and hold their heads high literally and metaphorically as they encounter various sociocultural obstacles.

\section{For Pooneh's Sake (2013)}

After two films for children, ${ }^{24}$ Alimardani wrote the script of and directed For Pooneh's Sake, his first feature film for the adult Iranian audience, one that succeeded in the box office and was popular with the viewers in different regions of Iran. ${ }^{25}$ It narrates the life of a young couple and through their domestic difficulties and differences, it presents some of the social challenges of Iranian women and how they surmount them. In the beginning of the film, we see the main male character, Majid in a drug rehabilitation camp. He is agitated for it is difficult for him to quit his addiction to different drugs. In the next scene, which occurs in a timeframe before his stay in the camp, we see Pooneh, his wife, returning to their apartment early from grocery shopping and finding Majid furtively using drugs. Then, the couple start a heated argument about Majid's addiction. At this scene, it is revealed that Majid, who has promised Pooneh to quit his addiction several times previously, cannot do it, and that he is a conservative and pseudo-patriarchal man, who is very controlling, constantly delusional, and severely suspicious of his wife. Majid is a typical character of the Iranian social films portraying the sociocultural challenges of women in Iran. He stands to benefit from "the patriarchal tradition" controlling and suppressing women, even as he attempts to be modern. However, he cannot fully accept and endorse "the reality of educated women in Iran today." ${ }^{26}$ And the conflict and contrast between Majid and his educated wife and how she manages their differences lies at the heart of the film's narrative.

For Pooneh's Sake, in a combination of the chronological narration and flashbacks, narrates the chaotic and deteriorating marriage of Majid and Pooneh. Majid is from a conservative and traditional Turkish-speaking family from the

\footnotetext{
${ }^{24}$ Alimardani wrote the script of and directed The Secret of Taran Desert (2010) and A Fugitive from Bagbo (2012).

${ }^{25}$ According to one official estimate, the film sold 512,000,000 tomans in 17 theater complexes in Tehran and 22 complexes in provinces in 3 weeks. Iranian Students' News Agency. "Forush-e 512 Milyuni-ye Beh Khāter-e Pooneh."

${ }^{26}$ Zeydabadi-Nejad, The Politics of Iranian Cinema, 105.
} 
provinces and Pooneh is from a modern and liberal family from the capital, Tehran. Majid's mother and sister dislike Pooneh because they believe she is too free and that a girl raised without a father cannot be a good girl. In addition, Majid's conservative mother censures Pooneh's mother because she does not wear the proper veiling in front of strange men. In contrast, Pooneh's mother and sister are educated and wear the more modern manteau and headscarf mode of veiling common in Tehran. Majid's mother only speaks Turkish, prevalent in the Turkish speaking provinces, in all the scenes where she appears, and Pooneh's mother speaks Persian, commonly spoken in Tehran. To highlight the linguistic difference between the couple, Alimardani underscores Pooneh's frustration as she does not understand Turkish when her husband and mother-in-law communicate in that language in front of her. In this manner, Alimardani involves the non-Turkish speaking viewers in the linguistic plight of Pooneh.

The religious, cultural, and linguistic contrast between the two families precipitate the disintegration of the marriage between Majid and Pooneh. In particular, Majid's addiction to drugs as well as his possessive approach to Pooneh take their toll on their relationship. Expecting Pooneh to be like his conservative mother, Majid is always suspicious of Pooneh and interrogates her about her daily schedule. In one occasion, he even hits her because she does not open the door of the apartment promptly enough, while in fact, as the camera reveals to the viewers, she has been in the bathroom and has not heard the doorbell ring. After frantically hitting her, he suspects there is another man in the apartment, so he takes a large kitchen knife and furiously tries to run outside the house and catch the imaginary lover, whose shadow he believes he has seen outside the window. It is only by Pooneh's intervention that he stops making a scene in the neighborhood. In another scene, revealing his inability to communicate effectively with his wife, we see that as he is fighting vigorously and loudly with Pooneh, he threatens to kill himself and even cuts his own wrist with a knife. Thus, we get the impression that even as he is delusional and possessive, Majid harbors some degree of love and respect for Pooneh and her views as he wants her to acknowledge his desires and opinion even at the expense of threatening to commit suicide.

The film reaches a turning point when Pooneh suggests they hire a tutor to teach her the Adobe Photoshop software so that she could work remotely as a professional photo editor. One of their mutual friends gives a tutor's business card to Majid and after some debate and initial resistance, Majid, who, reflecting his pseudo-patriarchal tendencies, does not want a male tutor to teach his wife, accepts to hire the tutor. Later in the film, we learn that Pooneh has known the tutor because he lives in her 
mother's neighborhood, and since she feared Majid would not agree to hiring him, she has asked their friend to pass the tutor's card to Majid. An always suspicious and apprehensive Majid finds out that Pooneh has known the tutor toward the end of the movie as his suspicions dramatically spiral and he starts to guard the house of the tutor, hoping that he could confront the man and discover about his assumed affair with Pooneh. After spending one night in his car parked in front of the tutor's house, he asks the tutor's mother about his whereabouts. The elderly woman states that her son has left Iran for Germany ten days ago. Relieved that the assumed lover of his wife is not in the country, Majid returns to his empty apartment and finds Pooneh's letter, in which she informs him she is finally leaving him and filing for divorce. The titles of the movie appear on the screen as we see the cabin of an airplane leaving Iran for Germany. Notably we do not see Pooneh on board. Thus, Alimardani leaves the viewers in an ambivalent position to decide for themselves if Majid's suspicions about Pooneh and the tutor are credible. Based on what we have seen in the film and Pooneh's repeated attempts to save her marriage in the film, we can, with some degree of certainty, conclude that she has not cheated on Majid. However, as the director and screenwriter, Alimardani tellingly leaves the final judgement regarding Pooneh and her assumed relationship with the tutor to the audience in the open-ended conclusion of the film.

In For Pooneh's Sake, Pooneh is the central character and exemplifies a strong, educated, independent, and intelligent Iranian woman. As Alimardani has stated in an interview, the film centers on Pooneh and her struggle to get "emotional divorce" from Majid, whom she initially loves but eventually comes to pity. ${ }^{27}$ Alimardani claims that it is inevitable and reasonable that Pooneh would break up the marriage after all the family and marital conflicts she encounters. ${ }^{28}$ Alimardani depicts Pooneh as an educated and intelligent woman who knows her rights and is capable of taking action when necessary. Although her husband is a drug addict, emotionally unavailable, controlling, and insulting, she nonetheless decisively stands her ground. She answers all his baseless suspicions and accusations respectfully. In a noteworthy scene, while the couple are crying after a fight, she asserts that it is not his right to treat her suspiciously and poorly, and it is not her right to be treated like that. Her farewell letter is a prime example of her indomitable will. In the letter she announces she does not regret her five years of marriage with Majid and admits they have had joyful and memorable moments. Then, without admonishing or vilifying him, she asserts their shared life and relationship cannot continue; therefore, she is leaving him. Proving

\footnotetext{
${ }^{27}$ Heydarabadi, "Hatef Alimardani."

${ }^{28}$ Tasnim News Agency. "Naghdi bar Film-e Beh Khāter-e Pooneh."
} 
that she respects the marriage and still has feelings for Majid, she even does not charge for her 6oo-gold-coin marriage dowry (almost 25 thousand dollars), to which she is legally entitled and can force Majid to pay.

Also noteworthy is that Alimardani posits his film in the context of his cinematic representation of the opposition between tradition and modernity. ${ }^{29}$ Through the difficulties that Majid and Pooneh as well as their families encounter in communicating with each other and overcoming their anxieties about their various cultural and linguistic differences, the film reflects on the tension between the traditional and modern social strata of contemporary Iran. Representing such difficulties as the main theme, the film introduces the audience to two distinct lifestyles. In other words, through the miscommunication and conflict between Majid and Pooneh, Alimardani encourages his viewers to rethink and reevaluate some of the taken-for-granted assumptions about the compatibility of tradition and modernity in contemporary Iran. Although Majid and Pooneh try to save their five-year-old marriage, their two distinct modes of life are incompatible, and consequently, their relationship is doomed to fall into disarray. And in the context of the conflict between tradition and modernity, Alimardani realistically represents an educated and modern Iranian woman who tries to salvage her marriage to a pseudo-patriarchal and illtempered traditional drug addict, yet, when she realizes that the man is incorrigible, she takes legal action and files for divorce. In this light, their divorce could arguably symbolize the disjuncture between modernity and tradition in contemporary Iranian society.

\section{The Nameless Alley (2016)}

Another box-office hit and popular movie, ${ }^{30}$ The Nameless Ally revolves around the experiences of a lower middle class and traditional family living in an old house in a poor neighborhood of southern Tehran. The film has been praised by an Iranian film critic as a reliable representation of the life of people of the poor and conservative families of southern Tehran and the best work of Alimardani in 2016. ${ }^{31}$ Another critic, commending Alimardani's impartial representation of social problems in Iran, maintains that The Nameless Ally is a "social" film that truthfully depicts the lower

\footnotetext{
${ }^{29}$ Ardeshiri, "Beh Khāter-e Pooneh."

$3^{\circ}$ Only in 20 days in theaters, it sold 1,243,000,000 tomans in Tehran and provinces and was at the top of the Iranian box-office at the time of its screening in March 2016. Honar Online. "Kuche-ye Binām.”

${ }^{31}$ Khalili Fard, "Naghd-e Film-e Kucheh-ye Binām."
} 
middle class in Iran, and by revealing the complexities of their life, enables the viewers to sympathize and identify with the characters. ${ }^{32}$

The titular name of the alley where the family lives is symbolically significant as its anonymity exemplifies the non-specificity of the experiences of its residents. In other words, by not specifying the name of the alley, Alimardani relays to his audience that the story could occur in any of the similar alleys in southern Tehran. As observed by Mehrnaz Saeed-Vafa, in contemporary Iranian films, location functions as "an aspect of the filmmaker's psyche and identification with a particular culture at a given time." 33 For filmmakers, such as Alimardani, "the choice of location is a cultural and at times a political statement, which consciously or unconsciously reveals aspects of the filmmaker's personal identity as well as his or her attitude toward the dominant culture." 34 Thus, Alimardani's selection of the "nameless" alley indicates his attempt to present a generic alley that could be identified as any of the allies in the poor neighborhoods of southern Tehran. In other words, his film speaks to the experience of a considerable number of Iranians. And its box-office success demonstrates his success in portraying a realistic and acceptable picture of their lives to his Iranian viewers.

The old house in the nameless alley is occupied by a large and conservative family. The patriarch of the family and the owner of the house, Hāj Mehdi lives with his wife and two daughters in the second floor, while his widow cousin, Forugh and her son and daughter live on the first floor. Forugh's son, Hamid is in love with the daughter of Hāj Mehdi, Nasibeh, but Forugh is adamantly against even the suggestion of their union, thus, the lovers must send each other secret letters and talk furtively. The other daughter of Hāj Mehdi, Mohaddeseh is having a secret relationship with a married man, who is eighteen years her senior. Inevitably, her relationship causes her problems when her conservative and religious mother, Ehterām sees her in the car of the man in the alley. Notably, her conservative mother does not castigate or insult her but confronts Mohaddeseh inquiring about the strange man. Mohaddeseh tells her the man is her suitor, and the mother wisely remarks that if the man is an honest suitor he will not hide himself and will sincerely talk to Mohaddeseh's family about his intention. Since the mother cannot convince Mohaddeseh about her mistake, she tells Hāj Mehdi about the incident. Therefore, a conservative and pious woman who has been raised in a patriarchal society resorts to a higher source of power, the patriarch

\footnotetext{
$3^{2}$ Movahhedi, "Naghd-e Film-e Kucheh-ye Binām.”

33 Saeed-Vafa, "Location (Physical Space) and Cultural," 200.

${ }^{34}$ Ibid., 202.
} 
of the family, in trying to reason with her daughter and change her mind about her nebulous relationship. At dinner, she tells Hāj Mehdi about Mohaddeseh's relationship and expects him to take some dramatic measures; however, the religious, conservative, and illiterate Hāj Mehdi, defying stereotypical perceptions of Muslim men, astutely replies that Mohaddeseh is an adult and the parents of adult children should not force their own wills on their children. In his view, if they compel Mohaddeseh to reluctantly break off her relationship, then, she will distance herself from them and they will lose her.

The story comes to a critical turning point when Hamid leaves Tehran to work in a provincial city. He originally buys bus tickets, but Hāj Mehdi insists that he should go by an airplane, which is faster and more comfortable, and he even pays for the flight ticket. Before leaving, Hamid argues intensely with his mother and tells her he loves Nasibeh and declares that upon his return, he will talk to Hāj Mehdi about marrying her. After the argument, Hamid sits by the pond and writes a letter for Nasibeh, but he does not have the time to give it to her so he hides it somewhere in the house. Then, he leaves the house to spend the night in the airport and catch his early morning flight. The next day, the Iranian national television announces the airplane in which Hamid was flying has crashed into a mountain and all the passengers and the crew have died. Despite the sad news, Hamid's mother frantically daydreams that her son did not board the airplane and instead left for the province with a bus. Forugh is so devastated that she starts concocting and imagining phone calls from Hamid, whom she thinks is working in the provincial city.

Another turning point in the story concerns Hāj Mehdi's past. In one scene, while his family are sleeping on the roof, Ehterām tells her daughters about her husband's love for her. She tells the story of how Hāj Mehdi has waited two years for her to come out of her coma after an air raid by the Iraqi warplanes during the Iran-Iraq War (1980-1988). She tells her daughters that Hāj Mehdi has gone to the hospital every day for a year because of his love for her. However, a few days later and after Nasibeh finds the letter of the late Hamid, a new secret is revealed. Hamid has written that Hāj Mehdi is in fact his father and this new revelation unsettles Nasibeh, who has loved his own half-brother up this point in the film. Now she realizes why Forugh was vigorously opposing their marriage. A distraught Nasibeh, gives the letter to Mohaddeseh, who reads it and unable to believe the news, confronts her father. In an honest and intense conversation, Hāj Mehdi, while sobbing, reveals to Mohaddeseh that while Ehterām was in hospital, the doctors told him that she will never recover; therefore, he, who had two small children, decided to marry Forugh. He tells Mohaddeseh that Forugh selflessly took care of and loved his children like their own 
mother and when Ehterām regained consciousness, Forugh consented to a divorce, while she was pregnant with Hamid. Then, a relative agreed to marry Forugh and accept Hamid as his son without causing a scandal for Hāj Mahdi or Forugh. Later, when her husband died, Hāj Mehdi offered to take care of Forugh, Hamid, and her daughter by her late husband. Shocked, Mohaddeseh asks her father if her mother knows about this secret and he replies that he has never told Ehterām. The film ends in a surreal scene where we see Hāj Mehdi, now relieved of the burning burden of his secret, walking in the flower pasture of his childhood memories and basking in the melodies of the river and the wind as the camera zooms out.

The story of the brief marriage of Hāj Mehdi and Forugh is significant as it demonstrates that the conservative Iranian man does not abuse the powers his patriarchal society has offered him. Hāj Mehdi, who has married Forugh while he and the doctors thought Ehterām would never regain her consciousness, is genuinely penitent. Although according to the Islamic law, which permits men to legally marry up to four women, Hāj Mehdi has not made a fault, he cries in front of his daughter as he is telling her about his experience for he cannot easily discard his marriage to Forugh and his hiding it from Ehterām. Forugh's second husband is another male character who does not conform to the stereotypical and essentialist portrayals of Muslim and conservative men suppressing women and benefitting from the powers the patriarchy invests in them. He agrees to marry Forugh without scandalizing her and even accepts to raise her son from a previous marriage.

The film also introduces three strong female characters. Ehterām, a pious and zealously religious woman who in her first appearance on screen is lying in her bed wearing her white burial shroud. When Mohaddeseh finds Ehterām in the shroud and is shocked, Ehterām tells her that she is preparing herself for her death and the afterlife. Ehterām attends weekly women's religious ceremonies in the local mosque with like-minded conservative women. Despite her religiosity and conservatism, she is not under control of her husband and while wearing her full body veiling moves around the city and accomplishes her daily tasks comfortably. Mohaddeseh is another strong character, who appears with heavy make-up in most of the scenes. Although she is reprimanded by Ehterām because of her make-up and assumed frivolity, she is not forced by her parents to toe the line. Her conservative parents responsibly perform a supervisory role for Mohaddeseh and her sister, Nasibeh. Both Mohaddeseh and Nasibeh, wear the manteau and scarf, which are the veiling of modern women, and attend university. It is significant that both girls attend a university and thus are establishing their position in the more educated and modern strata of Iranian society. According to one official estimate for the academic year 2016-2017, there were 
$1,723,269$ female students attending various colleges and universities in the country. ${ }^{35}$ Thus, the character's being university students adds to the realistic appeal of the film for the viewers. In sum, The Nameless Alley, by focusing on a conservative, traditional, and lower middle-class family, demonstrates how Islam or the patriarchy do not define Iranian men and women, who, similar to people in other countries, grapple with various social, cultural, and economic challenges. Thus, the film critiques the notion that Muslim women living in conservative communities are mentally or metaphorically imprisoned by their religion or men.

\section{$\bar{A}$ bā Jān (2017)}

Alimardani's Ābā Jān is, in his own words, "a naturalist and documentary" film about the life of Iranians during the Iran-Iraq War, ${ }^{36}$ and his best and most favorite film. ${ }^{37}$ His motivation to make the film has been depicting the hardships of Iranians living during the war and under the Iraqi air raids on their cities. ${ }^{38}$ Reflecting its popularity among Iranian viewers, $\bar{A} b \bar{a}$ Jān was selected "The Best Film by the Viewers" in the $25^{\text {th }}$ Fajr Film Festival in $2017,{ }^{39}$ and in a few weeks after its release, became a boxoffice success in Iran. ${ }^{4^{\circ}}$ Praising $\bar{A} b \bar{a} J a ̄ n$, a prominent Iranian film critic maintains that Alimardani has successfully created real-life and non-exaggerated characters in $\bar{A} b \bar{a}$ Jān and that he has constructed a multi-faceted and credible titular character, exemplifying a strong, conservative, and pious Iranian woman. ${ }^{41}$ Pointing to its success in portraying a realistic picture of Iranian society during the war, another critic praises $\bar{A} b \bar{a}$ Jān as "a completely Iranian film," whose characters replicate real-life people to the extent that the viewers can identify and sympathize with them. ${ }^{42}$

A tribute to Alimardani's own grandmother, $\bar{A} b \bar{b} J a \bar{n}$ revolves around the story of $\bar{A} b \bar{b} \mathrm{Jān},{ }^{43}$ a conservative and resilient elderly woman, and her family in the provincial city of Zanjan during the Iran-Iraq War. The main characters live in a moribund old man's house, where his two wives, as well as one of his daughters alongside her

\footnotetext{
${ }^{35}$ Iranian Students' News Agency. “Daneshgāhhā-ye Iran.”

${ }^{36}$ Mehr News Agency. "Ābā Jān."

${ }^{37}$ HodHod Media. "Naghd-e Film-e Ābā Jān.”

${ }^{38}$ Mehr News Agency. "Ābā Jān."

39 Pars Today. "Negāhi be Filmhā-ye Bargozideh."

$4^{\circ}$ In a few weeks after its release, it sold 1.300.000,00o tomans in Iran. Iranian Students' News Agency. "Ākharin Āmār-e Forush."

${ }^{41}$ Ja'fari Rad, "Mo'arrefi va Naghd-e Film-e Ābā Jān.”

$4^{2}$ Kharraziha, "Negāhi be Ābā Jān."

43 In Azeri Turkish the word "Ābā Jān” means "dear mother."
} 
husband and children live together. The story is narrated through the perspective of Ābā Jān, the second wife of the old man and the de facto matron of the family, assisting all its members with different problems. As the narrative progresses we gradually learn that although Ābā Jān has been wronged by her husband, who has married a younger girl, lives in an extremely patriarchal society, where women are not permitted to be seen with men and use make-up, and suffers for her son, who is missing at war, she nonetheless resiliently manages the affairs of the entire family. Her centrality in the film is highlighted in the very first scene where we see her on the screen as the camera follows her walking to the bazaar, doing her grocery shopping, eating lunch in a small restaurant, and returning to the house. And her importance in her family is underscored in the first scene when the camera shows her in the house. Some ten minutes into the film, the camera zooms in on one of the rooms of the house, where the old man is lying unconscious on his bed, while all the members of his family surround him. Notably, Ābā Jān is the focus of the frame and the camera positions her at the very center of the family, as she is sitting by the bed of the old man and reading the Quran for his heath.

As the family encounters different crises, both the men and the women, call her name and refer to Ābā Jān for guidance and assistance. As a matter of fact, we learn about different crises in the family through the perspective of Ābā Jān while the camera follows her as she learns about the crises. The first crisis is the episode in the house where the old man is lying unconscious on the bed and all his family members think he is going to die. But, Ābā Jān consoles and comforts the family by reading the Quran and praying for his health. A few days later when Ābā Jān returns home from her daily shopping, she finds the house in chaos. Her son-in-law has found out his daughter has been seen with a boy-although the boy has been harassing the young girl-and is infuriated and wants to punish the girl to defend his honor. When his daughter notices that Ābā Jān is home, she calls her name for help. Fearing her father, the young girl has locked herself in the storage room; therefore, Ābā Jān distracts her fuming son-in-law and enters the storage room to inquire the girl about the truth of the matter. After she realizes the girl is innocent and has been harassed by a young man, Ābā Jān pretends she is disciplining and hitting the girl while hitting a sack of rice and shouting at the girl, who plays along Ābā Jān's plan. Thus, Ābā Jān calms her son-in-law and resolves the issue. As the house is engulfed in the shouts of the angry son-in-law, the next crisis occurs. While Ābā Jān and her granddaughter are in the storage room, her grandson eats a piece of opium he has found under the fridge. Ābā Jān's daughter finds him lying unconscious on the ground, and the first thought crossing her mind is Ābā Jān. Distraught, she calls the name of Ābā Jān for help. Ābā 
Jān leaves the storage room, holds the little boy, makes him throw up, gives him milk, and forces his father to immediately take the boy to the hospital. She even follows her daughter, son-in-law, and the boy to the hospital and remains there for the night until the boy gets better. In another critical episode, and a few days later, the police arrest Ābā Jān's stepson because he has been hiding anti-government political leaflets among his belongings. Once again, the viewers learn about this crisis through Âbā Jān. The camera follows her through alleys as she walks back home and finds out her stepson is in prison. The boy's mother, the second wife of the old man, refers to Ābā Jān for aid, and only after Ābā Jān, as a respectable woman in the local community, calls the police, they release her stepson. A few days later, Ābā Jān's daughter finds out that her daughter has eloped with Ābā Jān's stepson. Distressed and fearful of the fury of her husband, she seeks Ābā Jān for aid. As Ābā Jān's son-in-law is fighting with his wife about the girl's elopement, the camera shows Ābā Jān in her room watching television. The newscaster announces that her son is among the prisoners of war held in Iraq, thus, she starts crying uncontrollably as she finds out her long missing son, whom everybody believed was dead, is still alive. The camera follows Ābā Jān as she walks into the yard and her son-in-law and daughter, who have never seen her crying, stop their argument and surround her. The final crisis of the film, which is not only that of the family but of the entire city, occurs a few days later. When Ābā Jān's son-in-law, who is on the house's roof, notices the elementary school has been bombed by an Iraqi fighter jet, he calls the name of Ābā Jān for aid. Ābā Jān immediately runs toward the school. The film ends as Ābā Jān stands in front of the destroyed and burning elementary school, while people are carrying the injured and the dead boys out of the building, and the camera zooms on her face. In this final scene, through her desperation and grief, the viewers are offered a glimpse into the desperation and grief of the entire city of Zanjan.

Ābā Jān is not merely portrayed as a compassionate woman assisting the others, but also a strong-willed individual in her own personal life. Although all her family and friends tell Ābā Jān her son has died in war, she adamantly and with her motherly instinct believes that he is still alive. She even goes to the local mosque, where the government soldiers are stationed, and suggests going to the war front herself to find him. However, one of the soldiers tells her he has done extensive research and asked everybody to make sure about the fate of her son, and he does not allow her to go to the war front. In another noteworthy scene, as Ābā Jān is recounting the sorrowful story of her ill-fated life for her granddaughter, she merely reports the facts objectively. She reveals that her husband has always been bellicose and irascible, has not assisted her with raising the children, and even has brought his young cousin to 
the house and married her as his second wife. Notably, when Ābā Jān's granddaughter speechlessly stares at her, Ābā Jān unconcernedly asks if she has become amazed at her black fate. Therefore, while Ābā Jān assists everybody around her, including his cheating and now moribund husband, her children, and grandchildren, she is also strong-willed and unwavering in her most personal emotions regarding her only son and her own life. She is not caged mentally or imprisoned by her veiling or position as a woman in an Islamic society, but receives respect from her family and community as she freely goes around her with different challenges of her life.

$\bar{A} b \bar{a} J \bar{n}$, Alimardani's most favorite social film, is a reminder to the younger Iranian generations about the travails and tribulations of the older generations during the Iran-Iraq War. The film begins with a sequence in which children are in an underground shelter while the Iraqi airplanes bomb the city, and ends while Ābā Jān, overwhelmed and distressed, stares at the recently bombed and destroyed elementary school and a lachrymose mourning song plays. Therefore, Âbā Jān is portrayed as a representative of courageous Iranian women who went through the atrocities of the war. Furthermore, Ābā Jān functions as a symbol for the city of Zanjan, where Alimardani grew up and lost his classmates in an air raid on his elementary school during the war. In Ābā Jān, through Ābā Jān's encounter with various strata of Zanjan's society, an episode of the sociocultural life of Zanjan during the Iran-Iraq War is reconstructed cinematically. Ābā Jān's resilience, patience, and ultimate despair exemplify those of the city and its residents during the war as they were dealing with their daily lives, even as they were constantly in fear of the next bombing on the city. The final scene is particularly telling as camera focuses on the speechless, griefstricken, and inconsolable Ābā Jān while she is staring at the rubbles of the elementary schools. In conclusion, in $\bar{A} b \bar{a} J a \bar{n}$, we see that the full body veiling and the religious piety of Ābā Jān do not prevent her from fulfilling critical roles in her community. Moreover, the conservative men, even those who still believe in taking advantage of their patriarchal privileges or defending their honor by forcing their women to be reclusive cannot suppress Ābā Jān. In other words, we are once again exposed to an image of the Iranian Muslim woman who defies some Western stereotypical misrepresentations of the Muslim woman as a caged and imprisoned being.

\section{Conclusion}

The films by directors living in and focusing on Muslim societies constitute significant sources of information, with which we can criticize essentialist and stereotypical (mis)representations, and opt for realist appraisals of the sociocultural life of women 
in Muslim societies. To better understand the condition of Iranian women and the extent to which they are or are not restricted or imprisoned by Islamic rules, such as the mandatory hijab, and the patriarchy, the critically acclaimed and nationally popular realist social films of Hatef Alimardani were examined in this article. A prolific screenwriter and director, whose films have been phenomenally popular among Iranian viewers and critics, Alimardani offers realistic cinematic representations of Iranian society and real-life characters with which the Iranian viewers identify and sympathize; therefore, through his cinema we can access realistic vistas into Iranian society against the backdrop of misrepresentations of Muslim women.

In For Pooneh's Sake, Alimardani narrates the struggle of a strong, modern, and educated young woman to save her marriage to an irascible, conservative, and pseudopatriarchal drug addict. She discerningly navigates all her options, but when her cultural and linguistic differences with her husband and his family outweigh her efforts, she respectfully files for a divorce. In The Nameless Alley, Alimardani portrays university-attending young Iranian girls who courageously confront their traditional and conservative parents and demand to pursue their desires and life goals. And in $\bar{A} b \bar{a} J a ̄ n$, Alimardani presents a strong-willed, pious, and conservative woman, who despite living in a patriarchal society where women cannot wear make-up or be seen with strange men, having lost her only son for years, and wearing the full body hijab, manages an entire family on her shoulders.

In conclusion, Alimardani's social and realistic films portray traditional and modern Iranian women who ascertain and attain their rights and desires despite social and cultural limitations. Additionally, they show how all conservative Muslim men do not choose to benefit from the privileges patriarchy endows them. In this manner, Alimardani's films dismantle and critique the stereotypical portrayals of Muslim women as mentally and metaphorically imprisoned by Islamic mandates and the patriarchy. They challenge Western stereotypical misrepresentations of Muslim women and allow us a more unbiased and nuanced understanding of the sociocultural condition of Iranian women, in particular, and Muslim women, in general. 


\section{References}

Abu-Lughod, Lila. Do Muslim Women Need Saving? Cambridge, Harvard University Press, 2013.

Afshar, Haleh. Islam and Feminisms: An Iranian Case-Study. New York: Palgrave Macmillan, 1999.

Ahmed, Leila. Women and Gender in Islam: Historical Roots of a Modern Debate. New Haven: Yale University Press, 1992.

Al-Arian, Laila. "TV's Most Islamophobic Show.” Salon.

https://www.salon.com/test2/2012/12/15/tvs most islamophobic show/ (accessed July 24, 2020).

Ardeshiri, Mojtaba. "Beh Khāter-e Pooneh” [For Pooneh’s Sake]. TasnimNews.

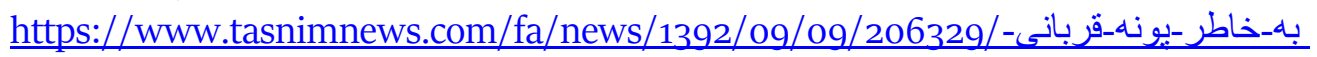
accessed July 20, 2020).

Dabashi, Hamid. Being a Muslim in the World. New York: Palgrave MacMillan, 2013.

Durkay, Laura. "Homeland' is the Most Bigoted Show on Television." WashingtonPost. https:/www.washingtonpost.com/posteverything/wp/2014/10/02/homeland-isthe-most-bigoted-show-on-television/ (accessed July 24, 2020).

Ebert, Roger. "Sex and the Islamic City." RogerEbert. https://www.rogerebert.com/reviews/circumstance-2011 (accessed July 24, 2020).

Hammer, Juliane. “Center Stage: Gendered Islamophobia and Muslim Women.” In Islamophobia in America: The Anatomy of Intolerance, edited by Carl W. Ernest, 107-144. New York: Palgrave MacMillan, 2013.

Heydarabadi, Sepideh. "Hatef Alimardani in Conversation with Borna News Agency." نخش-اخبار -143307/59-هانيه-تو سلى-با-مجيد-بـ/Borna.news. https://www.borna.news (accessed July 28, 2020).

Hirschmann, Nancy J. The Subject of Liberty: Toward a Feminist Theory of Freedom. Princeton: Princeton University Press, 2003.

HodHod Media. "Naghd-e Film-e Ābā Jān” [A Review of Ābā Jān]. https://hodhod.ca/نق_فيلم-آباجان_اكر ان-مونتر يال/2 (accessed July 24, 2020).

Honar Online. "Kuche-ye Binām" [The Nameless Alley]. https://www.honaronline.ir/-بخش-اخبار -7870/6وجه-بي-نام-در -صدر -جدول-فروش فيلم-هن (accessed July 19, 2020)

Iranian Students' News Agency. “Ākharin Āmār-e Forush” [The Latest Sale Statistics]. https://www.isna.ir/news/96012510128/آخرين_آمار -فروش-فيلم-هاى"

نوروزى(accessed July 22, 2020). 
Iranian Students' News Agency. "Dāneshgāhhā-ye Iran” [Iranian Universities].

https://www.isna.ir/news/97030804268/2دانشخاه_هاى-اير ان-به-رو ايت_آمار -و -ارقام" (accessed July 24, 2020).

Iranian Students' News Agency. "Forush-e 512 Milyuni-ye Beh Khāter-e Pooneh” [512

Million Sale of For Pooneh's Sake]. https://www.isna.ir/news/92071912289/-فروش

2512.0يليونى-باه-خاطر -يونه-يس-از-24-روز (accessed July 23, 2020).

Ja‘fari Rad, Mohsen. "Mo‘arrefi va Naghd-e Film-e Ābā Jān" [An Introduction to and

Review of Ābā Jān]. Hodhod.ca. https://hodhod.ca/نق_فيلم_آباجان_اكر ان-مونتريال

(accessed July 28, 2020).

Khalili Fard, Yasaman. "Naghd-e Film-e Kucheh-ye Binām” [A Review of The Nameless

Alley]. BaniFilm.ir. http://banifilm.ir/200324-2/ (accessed July 28, 2020).

Kharraziha, Shahram. "Negahi beh Ābā Jān” [A Review of Ābā Jān].

HamshahriOnline.ir. https://www.hamshahrionline.ir/news/367208/قصد_ای

اير انى-با-بازى_هاى-دلنشين (accessed July 28, 2020).

Mehr News Agency. “Ābā Jān.” https://www.mehrnews.com/news/3898192/-1 آباجان-ري يبر اي_فاطمه_معتمدآريا-ساختم_آباجان_مادربزرخ_من-بود ، (accessed July 16, 2020).

Milani, Farzaneh. Words not Swords: Iranian Women Writers and the Freedom of Movement. Syracuse: Syracuse University Press, 2011.

Mir-Hosseini, Ziba. Islam and Gender: The Religious Debate in Contemporary Iran. Princeton, NJ: Princeton University Press, 1999.

Moghissi, Haideh. Populism and Feminism in Iran: Women's Struggle in a MaleDefined Revolutionary Movement. New York: St. Martin's Press, 1994.

Moody, Nickianne. "Feminism and Popular Culture." In The Cambridge Companion to Feminist Literary Theory, edited by E. Rooney, 172-192. Cambridge: Cambridge University Press, 2006.

Movahhedi, Sudeh. "Naghd-e Film-e Kucheh-ye Binām" [Review of The Nameless Alley]. IslamicArtz.com.

http://www.islamicartz.com/story/RJcES7pKUl3AYxPsolpEgnbifmOEBtIdXeJx4VH QBRg (accessed July 28, 2020).

Naficy, Hamid. A Social History of Iranian Cinema. 4 vols. Durham: Duke University Press, 2011-2012.

Pars Today. "Negāhi be Filmhā-ye Bargozideh" [A Look at Selected Films]. https:/parstoday.com/dari/radio/uncategorised-i30711 (accessed July 22, 2020).

Rahimieh, Nasrin. "Capturing Cultural Transformation on Film: Makhmalbaf's $A$ Moment of Innocence.” Edebiyat 12, no. 2 (2001): 195-214. 
Saeed-Vafa, Mehrnaz. "Location (Physical Space) and Cultural Identity in Iranian Films." In The New Iranian Cinema: Politics, Representation and Identity, edited by R. Tapper, 200-214. London: I. B. Tauris. 2002.

Tasnim News Agency. "Naghdi bar Film-e Beh Khāter-e Pooneh" [A Review of For Pooneh’s Sake]. https://www.tasnimnews.com/fa/news/1392/10/03/229434/-نقدى (a) ير -فيلم-باه-خاطر -يونه-ساخته_هاتف_عليمرداني (accessed July 29, 2020).

Tyson, Lois. Critical Theory Today: A User-Friendly Guide. New York: Routledge, 2006.

Zempi, Irene and Neil Chakraborti. Islamophobia, Victimisation and the Veil. New York: Palgrave MacMillan, 2014.

Zeydabadi-Nejad, Saeed. The Politics of Iranian Cinema: Film and Society in the Islamic Republic. London: Routledge, 2010. 